\title{
Analisa Kinerja Pembangkit Listrik Dual-Fuel Kapasitas 40 Kw Berbasis Gasifikasi Limbah Sabut Kelapa Di PT. Indonesia Power Pesanggaran Bali
}

\author{
A.A Ngurah Wisnu Kusuma $a^{1)^{*}}$, ( Gusti Bagus Wijaya Kusuma ${ }^{1)}$, \\ A.A.I.A.S Komaladewi ${ }^{1}$ \\ 1) Jurusan Teknik Mesin, Fakultas Teknik, Universitas Udayana. \\ Kampus Bukit Jimbaran, Badung, Bali, Indonesia 80361 \\ Email: wisnukusuma7@yahoo.com, igbwijayakusuma@unud.ac.id, komaladewijegeg@gmail.com
}

\author{
doi: https://doi.org/10.24843/METTEK.2019.v05.i01.p04
}

\begin{abstract}
Abstrak
Telah dilakukan penelitian tentang kinerja pembangkit listrik dual-fuel $40 \mathrm{~kW}$ berbahan bakar solar dan bahan bakar hasil gasifikasi dari limbah sabut kelapa. Penelitian ini bertujuan untuk mengetahui konfigurasi laju alir udara pembakaran (AFR) terhadap daya keluaran mesin diesel dan penghematan minyak solar yang dihasilkan. Pengukuran dilakukan dengan mengukur konsumsi bahan bakar solar, laju alir gas produser, daya genset, dan konsumsi sabut kelapa pada bukaan valve inlet udara pembakaran setengah dan penuh dengan pemberian beban listrik 0-100\%. Data menunjukan bahwa konfigurasi laju alir udara pembakaran (AFR) yang baik digunakan adalah bukaan setengah dan kinerja mesin diesel dual-fuel menggunakan bahan bakar biomassa sabut kelapa mampu mengurangi konsumsi solar sebesar $41.4 \%$
\end{abstract}

Kata Kunci: Sabut Kelapa, Syngas, Mesin Diesel, Dual-Fuel.

\begin{abstract}
Research on the performance of $40 \mathrm{~kW}$ dual-fuel power plants with diesel fuel and gasification fuel from coconut fiber waste. This study aims to determine the configuration of combustion air flow rate (AFR) on diesel engine output power and saving diesel fuel produced. Measurements were made by measuring diesel fuel consumption, producer gas flow rate, generator power, and coconut fiber consumption at the opening of the half and full combustion air inlet valve by providing 0-100\% electric load. Data shows that the configuration of the combustion air flow rate (AFR) good to use is the half openings and the performance of dual-fuel diesel engines using coconut fiber biomass fuel can reduce diesel consumption by $41.4 \%$
\end{abstract}

Keywords: Coconut Fiber, Syngas, Diesel Engine, Dual-Fuel.

\section{PENDAHULUAN}

Tingkat pemakaian bahan bakar terutama bahan bakar fosil di dunia semakin meningkat seiring dengan semakin bertambahnya populasi manusia dan meningkatnya laju industri di berbagai negara di dunia, sehingga hal tersebut menimbulkan kekhawatiran akan terjadinya krisis bahan bakar baik saat ini maupun masa depan, itulah sebabnya dimunculkan sebuah pemikiran penggunaan energi alternatif yang bersih dan dapat di perbaharui. PT. Indonesia Power Pesanggaran Bali memiliki Pembangkit Listrik Tenaga Diesel berbasis Gasifikasi yang masih dalam tahap pengembangan. Dimana dalam operasi nya membutuhkan bahan bakar

*Penulis korespondensi,

Email : wisnukusuma7@yahoo.com 
minyak solar dan gas produser yang dihasilkan dari proses gasifikasi menggunakan biomassa. Biomassa yang digunakan sebaiknya adalah biomassa yang tidak memiliki kegunaan lain atau lebih ekonomis jika digunakan sebagai bahan gasifikasi dibandingkan jika digunakan untuk yang lain. Sabut kelapa merupakan salah satu bahan yang memenuhi kriteria tersebut. Gasifikasi merupakan cara mengkonversikan energi biomassa dalam hal ini sabut kelapa menjadi energi dalam bentuk gas dan dapat dimanfaatkan sebagai pembangkit listrik. Perlu diperhatikan sejauh mana energi biomassa dapat mempengaruhi besarnya daya listrik yang digunakan, apalagi jika di bebani dengan beban listrik yang besar. Oleh sebab itu perlu diteliti pengaruh pemakaian laju alir gas produser yang konstan hasil gasifikasi limbah sabut kelapa dengan memvariasikan laju alir udara pembakaran dan beban listrik terhadap kinerja Pembangkit Listrik Tenaga Diesel berbasis Gasifikasi Kapasitas 40 kW di PT. Indonesia Power Pesanggaran Bali.

\section{METODE}

Pengambilan data dilakukan dengan pengujian kinerja mesin diesel single-fuel sebagai data pembanding dan kinerja mesin diesel dual-fuel sebagai data utama dari penelitian ini. Data yang dapat diambil pada saat single-fuel yaitu konsumsi bahan bakar solar, daya genset pada bukaan valve inlet udara pembakaran penuh dengan rasio beban 0-100\%. Data yang diambil pada saat dual-fuel yaitu konsumsi bahan bakar solar, laju alir gas produser, daya genset, dan konsumsi sabut kelapa pada bukaan valve inlet udara pembakaran setengah dan penuh dengan pemberian beban listrik $0-100 \%$. Sehingga dapat memperoleh perbandingan konsumsi bahan bakar solar dan daya output yang dihasilkan.

\section{HASIL DAN PEMBAHASAN}

Pada penelitian ini diperoleh data kinerja mesin diesel dual-fuel yang akan membandingkan dan menghubungkan antara konsumsi bahan bakar solar, laju alir gas produser, daya genset dan konsumsi sabut kelapa dengan bukaan valve inlet udara pembakaran pada saat bukaan setengah dan bukaan penuh dengan pemberian beban 0\% hingga 100\%. Data tersebut dimuat dalam bentuk Grafik Perbandingan dan Grafik Hubungan yang ditunjukkan dibawah ini :

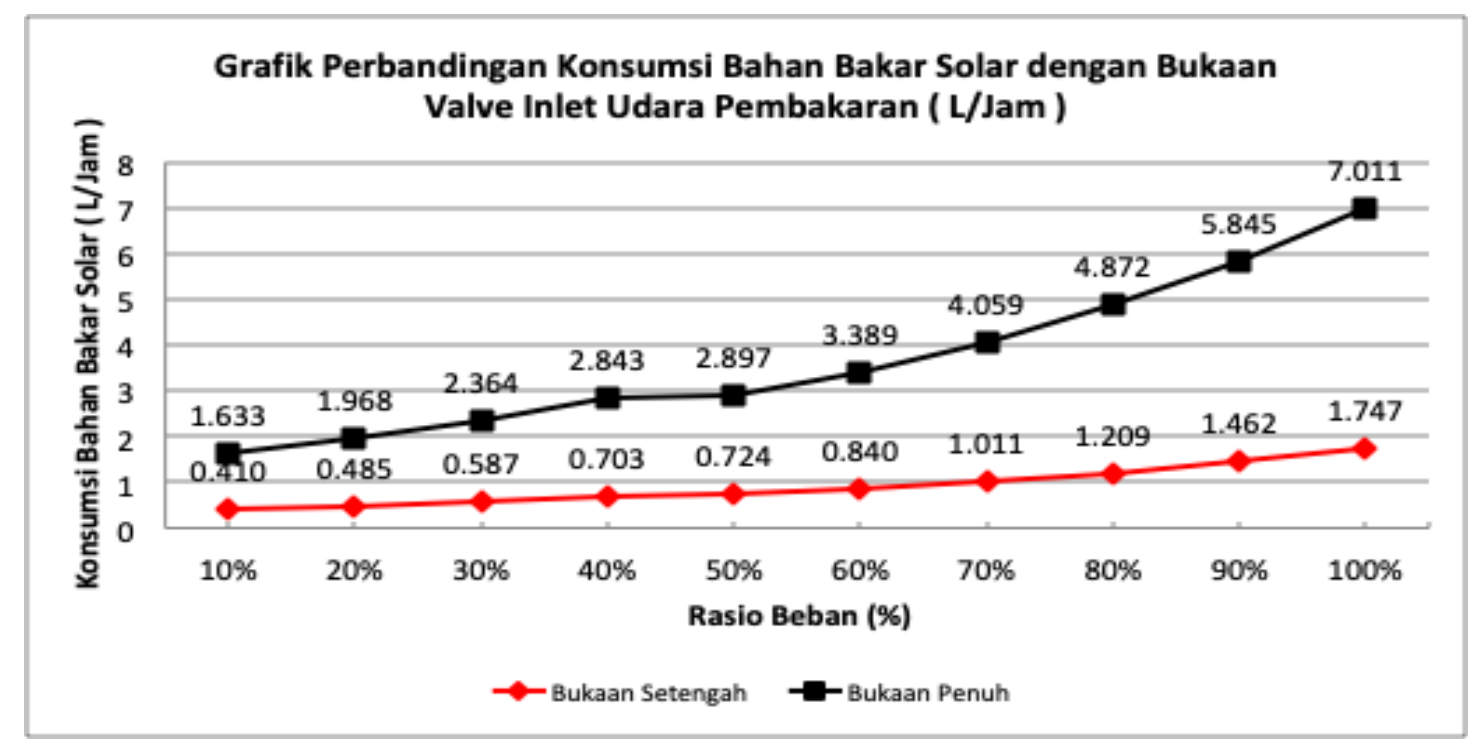

Grafik 1 Perbandingan Konsumsi Bahan Bakar Solar dengan Bukaan Valve Inlet Udara Pembakaran 
Jurnal METTEK Volume 5 No 1 (2019) pp 26 - 36

ojs.unud.ac.id/index.php/mettek

Pada Grafik 1 menunjukkan bahwa konsumsi bahan bakar solar mengalami peningkatan seiring dengan penambahan rasio beban listrik pada saat bukaan setengah maupun bukaan penuh, akan tetapi dilihat dari konsumsi bahan bakar solar pada saat bukaan penuh memerlukan konsumsi solar yang lebih besar dibandingkan bukaan setengah dalam L/jam. Data Konsumsi Solar diperoleh menggunakan persamaan :

KonsumsiSolar $=$ BeratAwalSolar - BeratAkhirSolar.

Contoh Perhitungan Konsumsi Solar pada Rasio Beban 10\% Bukaan Setengah dengan melakukan 2 kali percobaan :

1. Konsumsi Solar $=17.926 \mathrm{~kg}-17.870 \mathrm{~kg}=0.056 \mathrm{~kg} / 10 \mathrm{menit}$

2. Konsumsi Solar $=13.783 \mathrm{~kg}-13.719 \mathrm{~kg}=0.064 \mathrm{~kg} / 10 \mathrm{menit}$

Rata - rata Konsumsi Solar $=\frac{0.056 \mathrm{~kg}+0.064 \mathrm{~kg}}{2} \times 6=0.360 \mathrm{~kg} / \mathrm{Jam}$

Dikonversikan ke L/Jam $=\frac{0.360}{0.878}=0.410 \mathrm{~L} / \mathrm{Jam}$

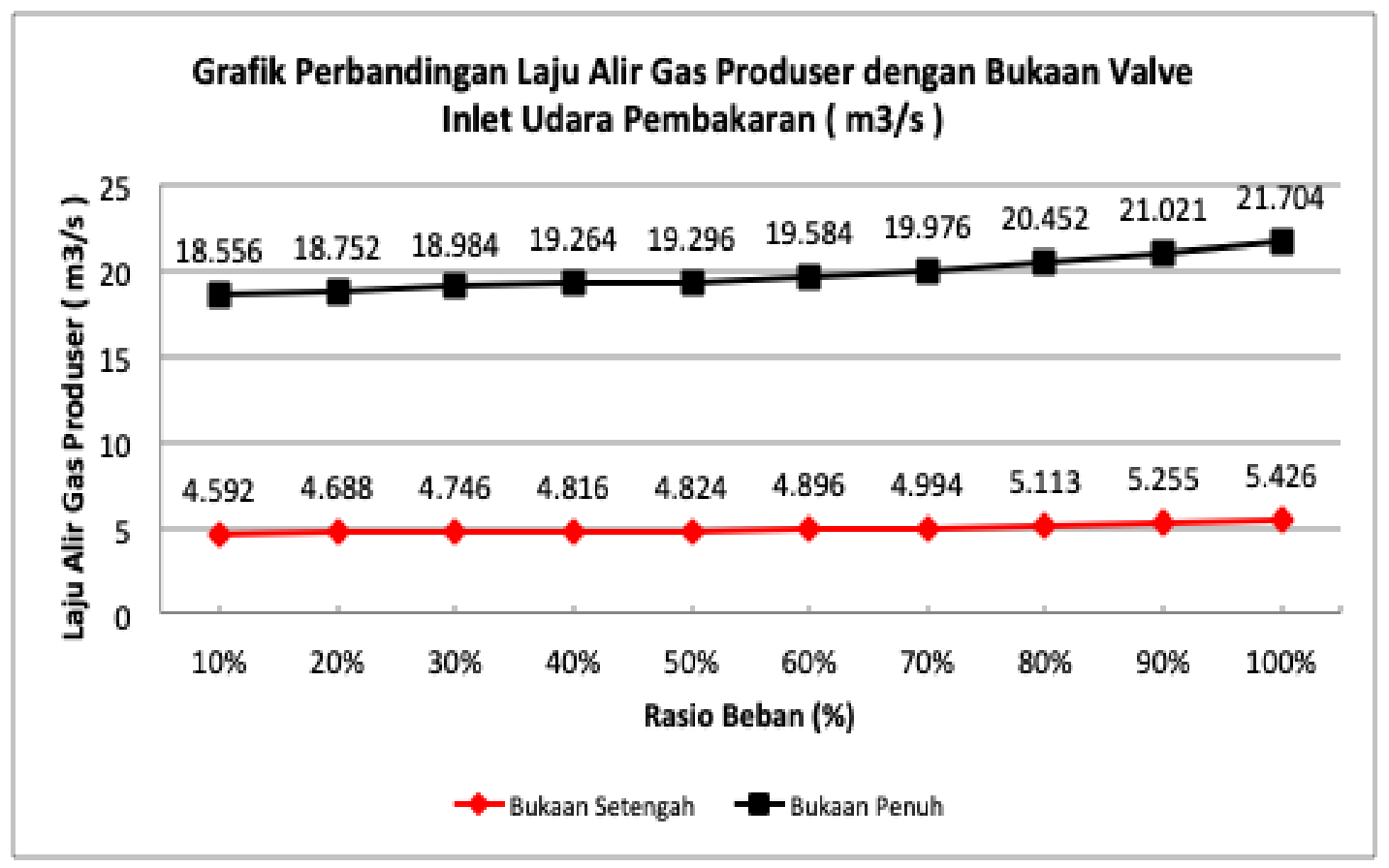

Grafik 2 Perbandingan Laju Alir Gas Produser dengan Bukaan Valve Inlet Udara Pembakaran

Pada Grafik 2 menunjukkan bahwa laju alir gas produser mengalami peningkatan seiring dengan penambahan rasio beban listrik yang dilakukan pada saat bukaan setengah maupun bukaan penuh, akan tetapi laju gas produser yang dihasilkan pada saat bukaan penuh lebih besar dibandingkan bukaan setengah. Data Laju Alir Gas Produser diperoleh menggunakan persamaan

$\dot{m}=\rho \cdot v \cdot A$

Contoh Perhitungan Laju Alir Gas Produser pada Rasio Beban 10\% Bukaan Setengah :

$$
\begin{aligned}
& \rho=1.2 \mathrm{~kg} / \mathrm{m}^{3} \\
& v=\frac{m}{s}=\frac{2.11 \mathrm{~m}}{0.27 \mathrm{~s}}=7.81 \mathrm{~m} / \mathrm{s}
\end{aligned}
$$




$$
\begin{aligned}
& A=\pi . r^{2}=3.14 \times 0.0125^{2} \mathrm{~m}=0.00049 \mathrm{~m}^{2} \\
& \dot{m}=1.2 \mathrm{~kg} / \mathrm{m}^{3} \times 7.81 \mathrm{~m} / \mathrm{s} \times 0.00049 \mathrm{~m}^{2} \\
& \dot{m}=0.004592 \times 10^{3} \mathrm{~m}^{3} / \mathrm{s} \\
& \dot{m}=4.592 \mathrm{~m}^{3} / \mathrm{s}
\end{aligned}
$$

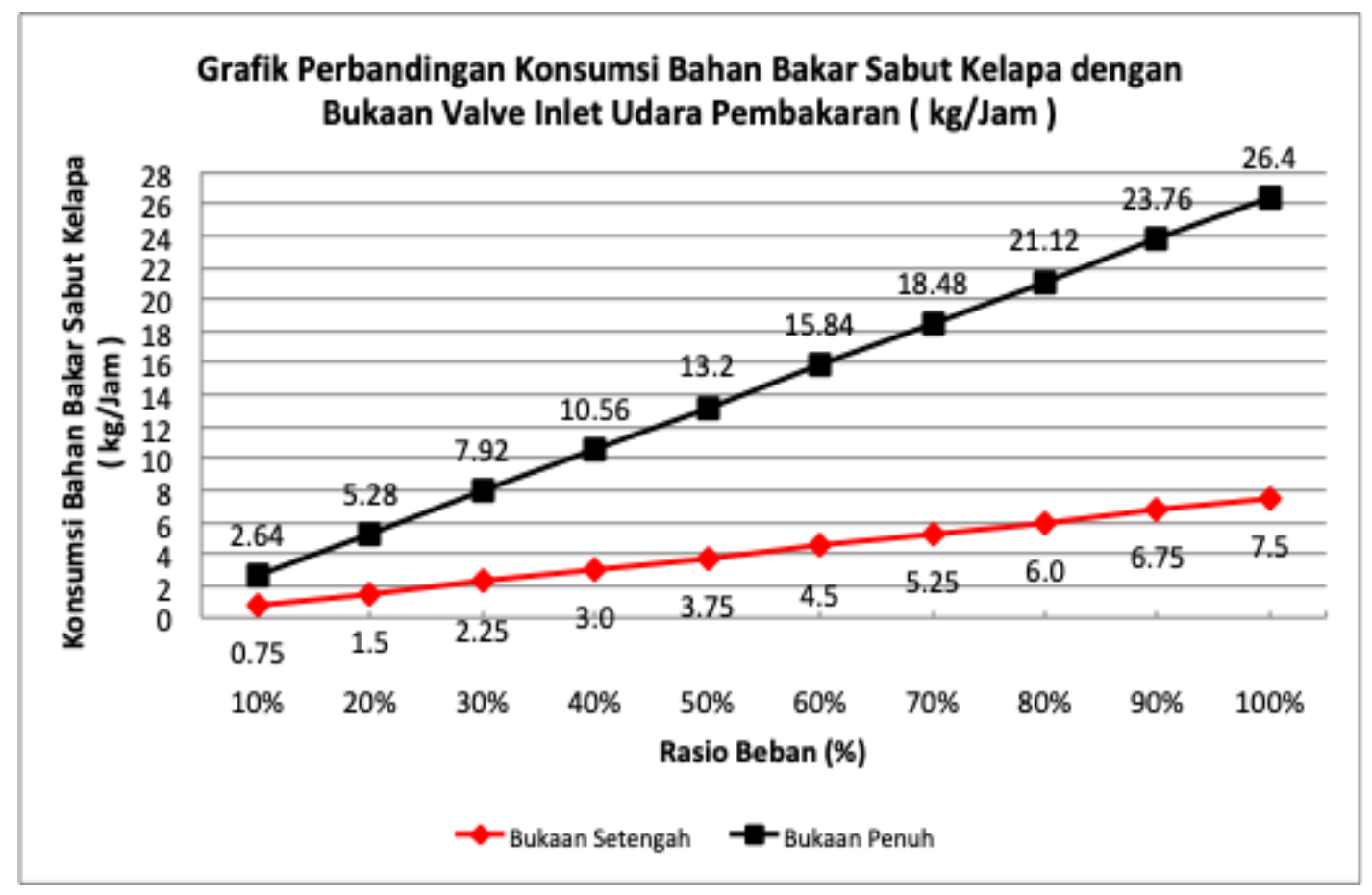

Grafik 3 Perbandingan Konsumsi Bahan Bakar Sabut Kelapa dengan Bukaan Valve Inlet Udara Pembakaran

Pada Grafik 3 menunjukkan bahwa Konsumsi Bahan Bakar Sabut Kelapa mengalami peningkatan seiring dengan rasio beban yang meningkat. Tetapi pada bukaan penuh memerlukan konsumsi sabut kelapa yang lebih besar dibandingkan bukaan setengah dalam $\mathrm{Kg} / \mathrm{Jam}$. Data Konsumsi Bahan Bakar Sabut Kelapa diperoleh menggunakan persamaan :

$$
\text { KonsumsiBahanBakarBiomassa }=\frac{\text { Biomassayangdigunakan }(\mathrm{kg})}{\text { WaktuOperasiGenset }(\text { menit })} .
$$

Contoh Perhitungan pada saat Bukaan Setengah dengan Rasio Beban 100\% :

Konsumsi Bahan Bakar Biomassa $=\frac{25(\mathrm{~kg})}{200(\text { menit })}=0.125 \mathrm{~kg} /$ menit

$$
=7.5 \mathrm{~kg} / \mathrm{Jam}
$$

Contoh Perhitungan pada saat Bukaan Penuh dengan Rasio Beban 100\% :

Konsumsi Bahan Bakar Biomassa $=\frac{100(\mathrm{~kg})}{224(\text { menit })}=0.44 \mathrm{~kg} /$ menit

$$
=26.4 \mathrm{~kg} / \mathrm{Jam}
$$


Jurnal METTEK Volume 5 No 1 (2019) pp 26 - 36

ojs.unud.ac.id/index.php/mettek

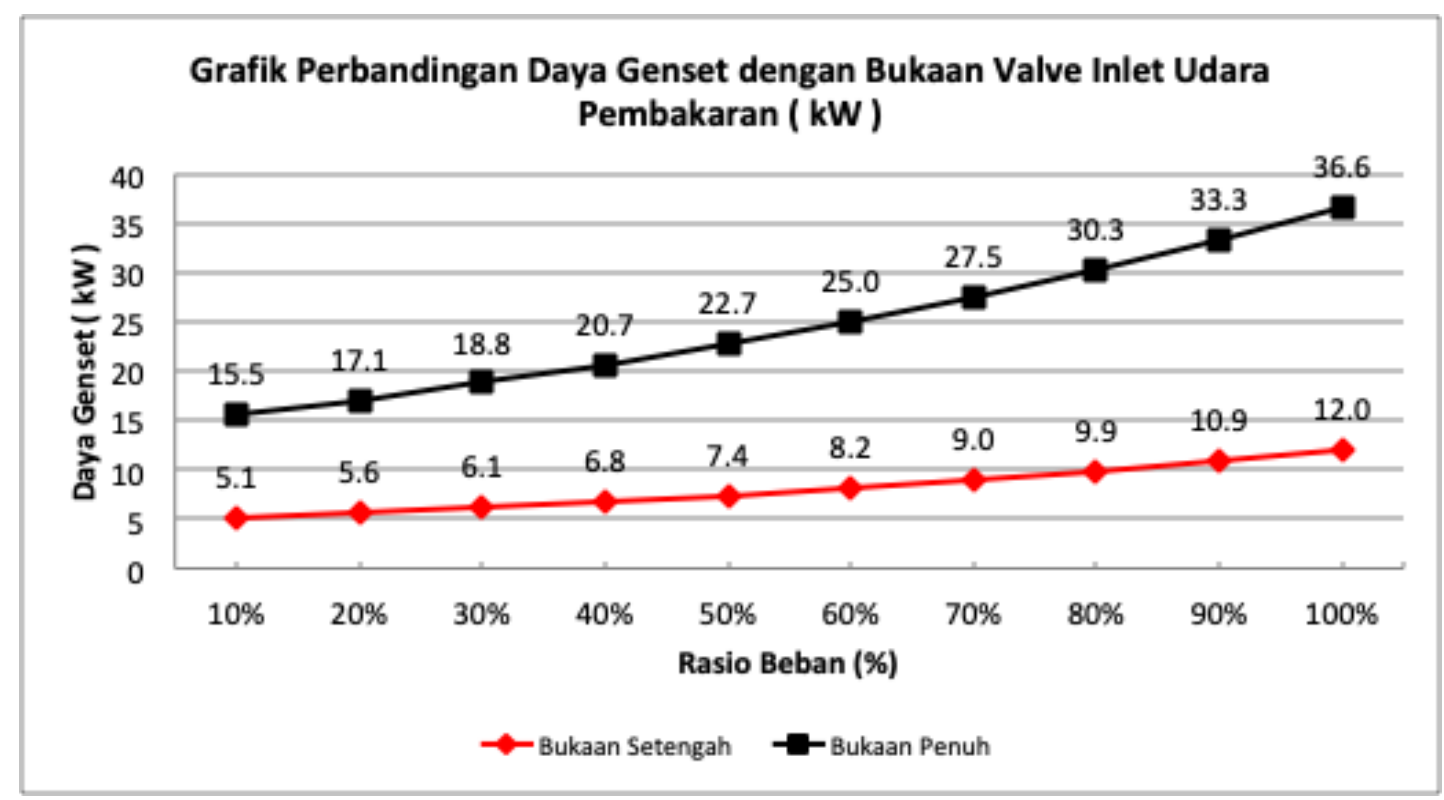

Grafik 4 Perbandingan Daya Genset dengan Bukaan Valve Inlet Udara Pembakaran

Pada Grafik 4 menunjukkan bahwa apabila rasio beban listrik bertambah maka daya genset yang dihasilkan mengalami peningkatan pada saat bukaan setengah maupun bukaan penuh. Tetapi apabila ingin memperoleh daya yang sama seperti bukaan penuh, pada bukaan setengah memerlukan waktu dan kinerja mesin lebih lama dibandingkan bukaan penuh yang dapat dihitung menggunakan perhitungan :

\section{Perbandingan Daya $=$ Daya Bukaan Penuh $:$ Daya Bukaan Setengah}

Contoh pada rasio beban $100 \%$ :

Perbandingan Daya $=36.6 \mathrm{~kW}: 12 \mathrm{~kW}=3.05: 1$

Dapat diketahui bahwa pada rasio beban 100\%, bukaan setengah menghasilkan $12 \mathrm{~kW}$ yang membutuhkan waktu dan kinerja mesin 3.05 kali lebih lama untuk mecapai daya $36.6 \mathrm{~kW}$ pada saat bukaan penuh. 


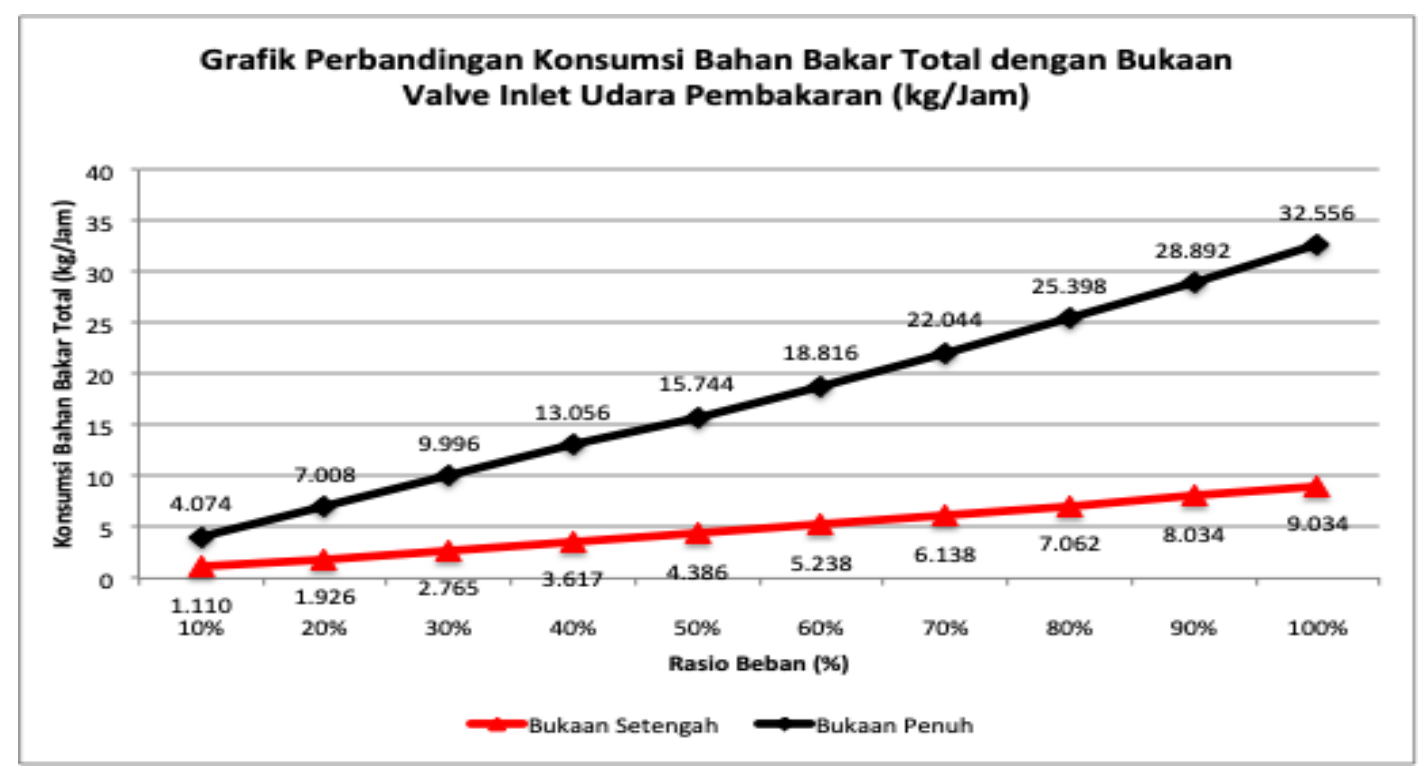

Grafik 5 Perbandingan Konsumsi Bahan Bakar Total dengan Bukaan Valve Inlet Udara Pembakaran

Pada Grafik 5 menunjukkan bahwa pada bukaan penuh memerlukan Konsumsi Bahan Bakar Total lebih besar dibandingkan bukaan setengah dalam Kg/Jam. Data Konsumsi Bahan Bakar Total diperoleh menggunakan persamaan :

Konsumsi $B B$ total $=$

Konsumsi BB Solar $(\mathrm{kg})+$ Konsumsi BB Biomassa $(\mathrm{kg})$...

Contoh Perhitungan pada saat Bukaan Setengah dengan Rasio Beban 10\%:

Konsumsi $B B$ total $=0.360 \mathrm{~kg} / \mathrm{Jam}+0.75 \mathrm{~kg} / \mathrm{Jam}=1.110 \mathrm{~kg} / \mathrm{Jam}$

Dari data diatas, dapat diketahui Selisih Bahan Bakar Total untuk memperoleh daya genset yang sama pada saat bukaan penuh menggunakan perhitungan :

Selisih Bahan Bakar Total $=\left(\left(\right.\right.$ Konsumsi B $B_{\text {total }}$ Bukaan Penuh

- (Perbandingan Daya $x$ Konsumsi B $B_{\text {total }}$ Bukaan Setengah))

Contoh Perhitungan pada Rasio Beban 100\%:

Selisih Bahan Bakar Total $=((32.556-(3.05 \times 9.034))$

$=(32.556-27.553)$

$=5.003 \mathrm{~kg} / \mathrm{Jam}$

Dari perhitungan diatas dapat diketahui bahwa untuk memperoleh daya genset $36.6 \mathrm{~kW}$ seperti bukaan penuh, konsumsi bahan bakar total bukaan setengah pada rasio beban $100 \%$ dapat menghemat bahan bakar $5.003 \mathrm{~kg} / \mathrm{Jam}$. Dapat diartikan bahwa bukaan setengah lebih irit bahan bakar dibandingkan bukaan penuh. 


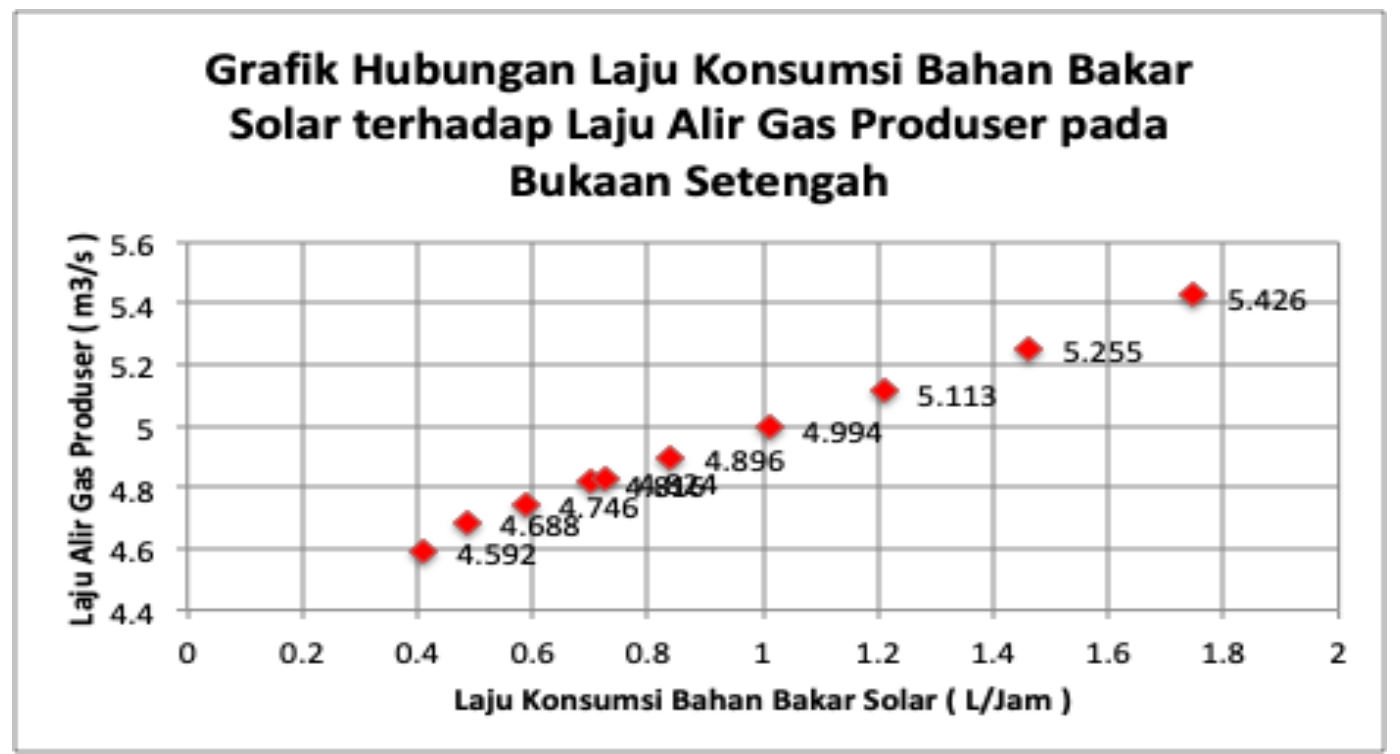

Grafik 6 Hubungan Konsumsi Bahan Bakar Solar terhadap Laju Alir Gas Produser pada Bukaan Setengah

Pada Grafik 6 menunjukkan bahwa pada bukaan setengah, bertambahnya konsumsi bahan bakar solar mempengaruhi peningkatan laju aliran gas produser.

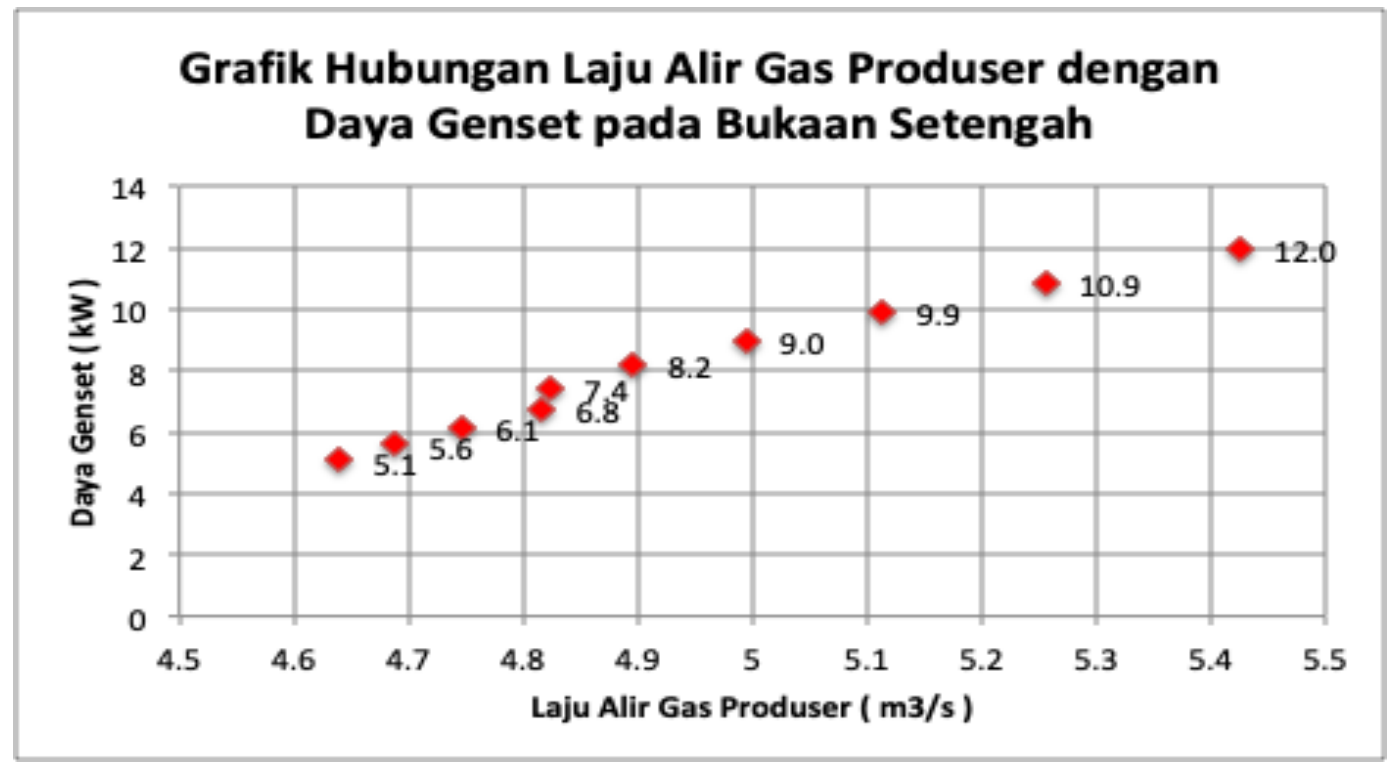

Grafik 7 Hubungan Laju Alir Gas Produser dengan Daya Genset pada Bukaan Setengah

Pada Grafik 7 menunjukkan bahwa pada bukaan setengah, bertambahnya laju aliran gas produser mempengaruhi peningkatan daya genset. 


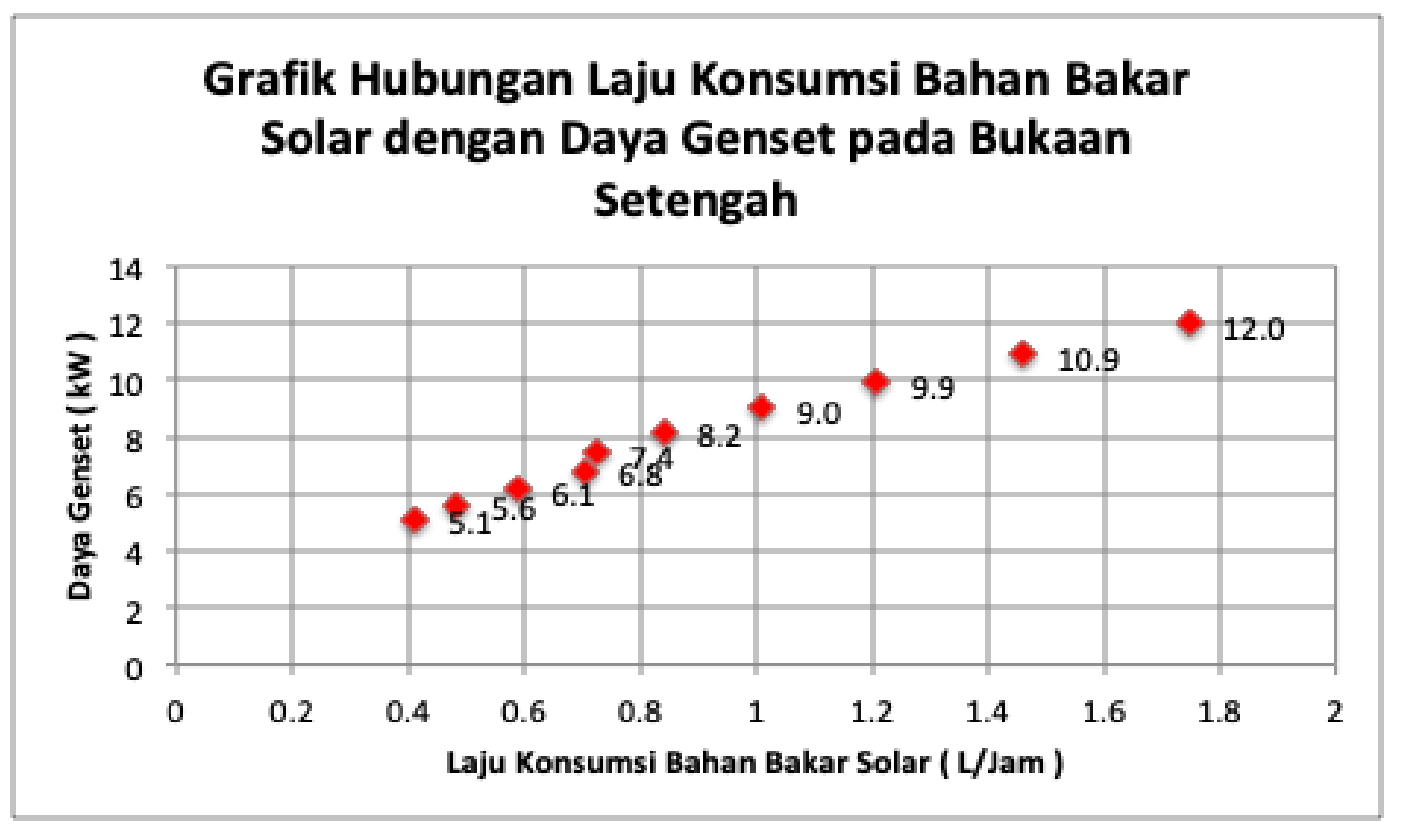

Grafik 8 Hubungan Konsumsi Bahan Bakar Solar dengan Daya Genset pada Bukaan Setengah

Pada Grafik 8 menunjukkan bahwa pada bukaan setengah, bertambahnya konsumsi bahan bakar solar mempengaruhi peningkatan daya genset.

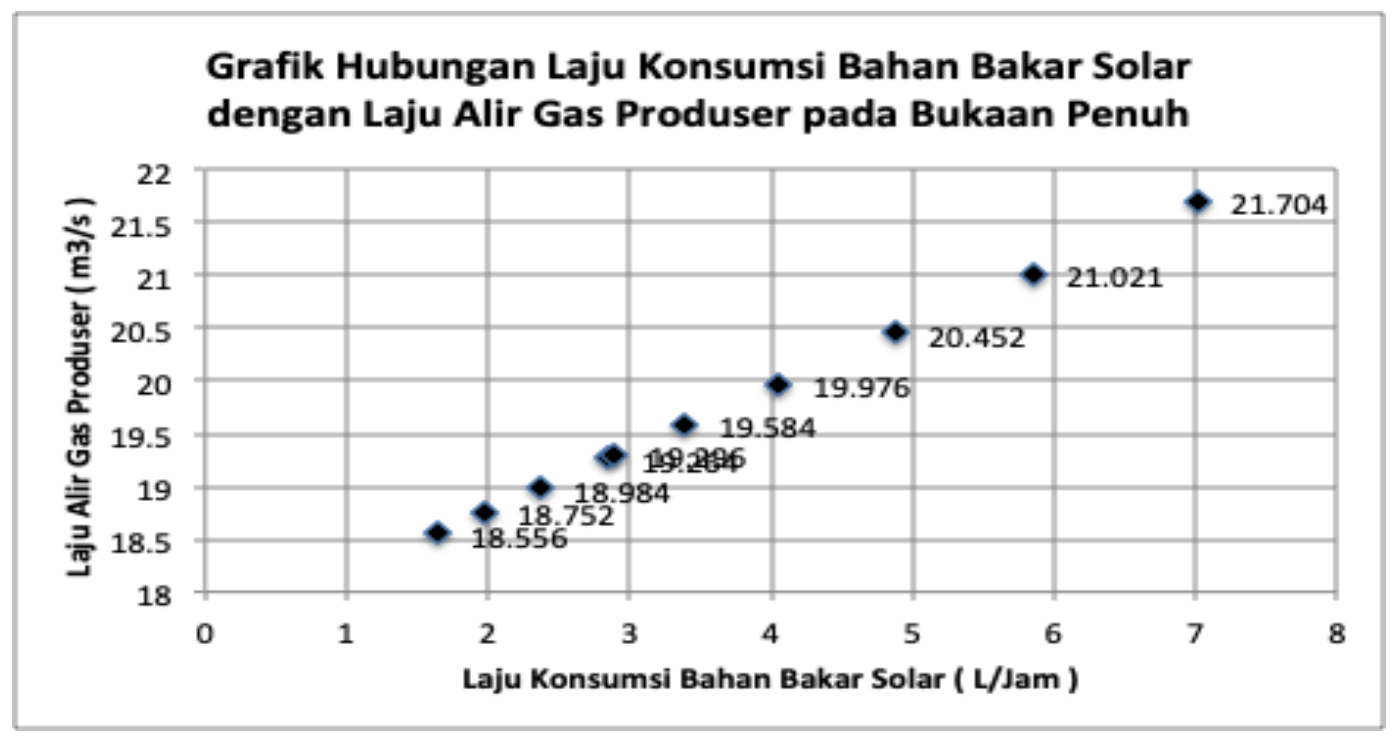

Grafik 9 Hubungan Konsumsi Bahan Bakar Solar dengan Laju Alir Gas Produser pada Bukaan Penuh

Pada Grafik 9 menunjukkan bahwa pada bukaan penuh, bertambahnya konsumsi bahan bakar solar mempengaruhi peningkatan laju alir gas produser. 
Jurnal METTEK Volume 5 No 1 (2019) pp 26 - 36

ojs.unud.ac.id/index.php/mettek

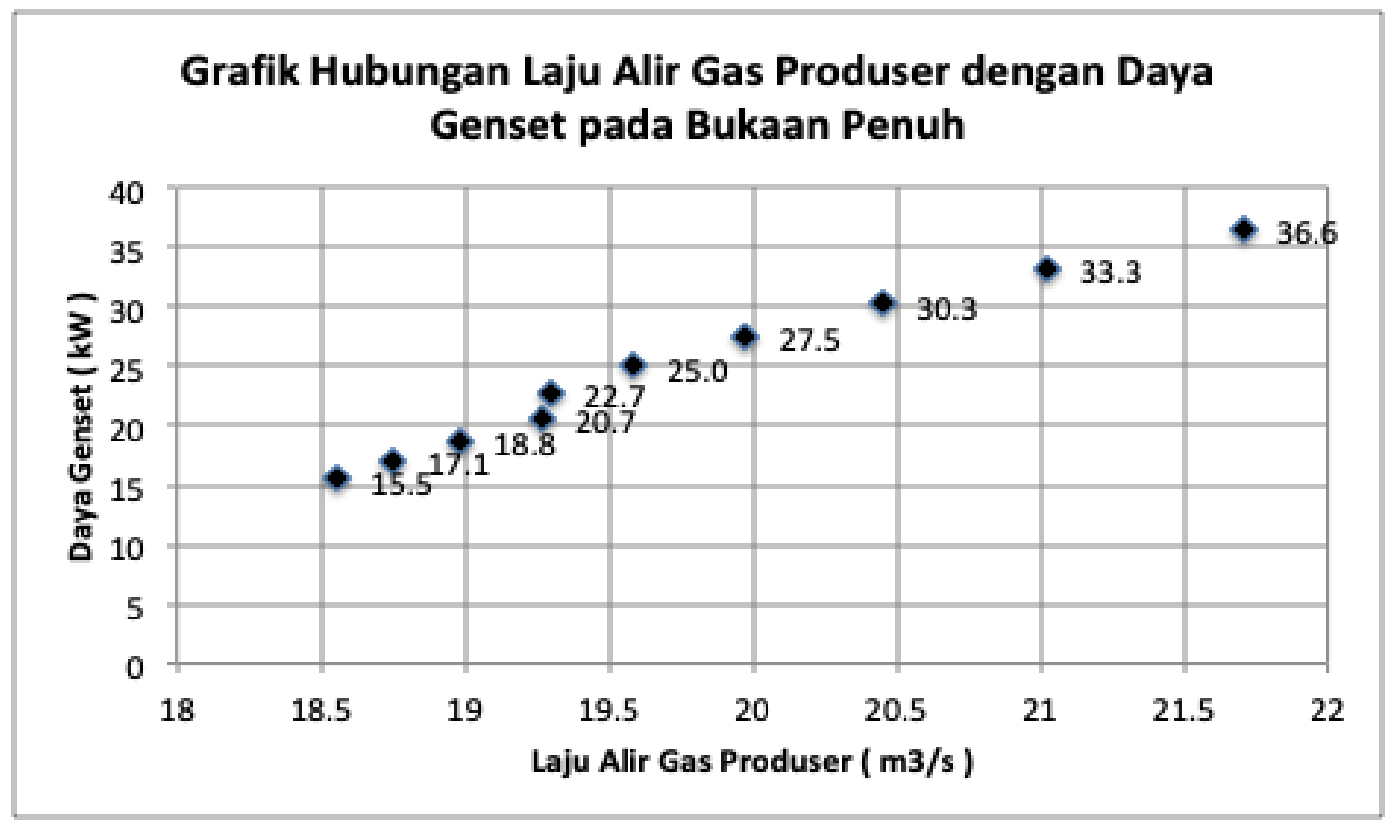

Grafik 10 Hubungan Laju Alir Gas Produser dengan Daya Genset pada Bukaan Penuh

Pada Grafik 10 menunjukkan bahwa pada bukaan penuh, bertambahnya laju aliran gas produser mempengaruhi peningkatan daya genset.

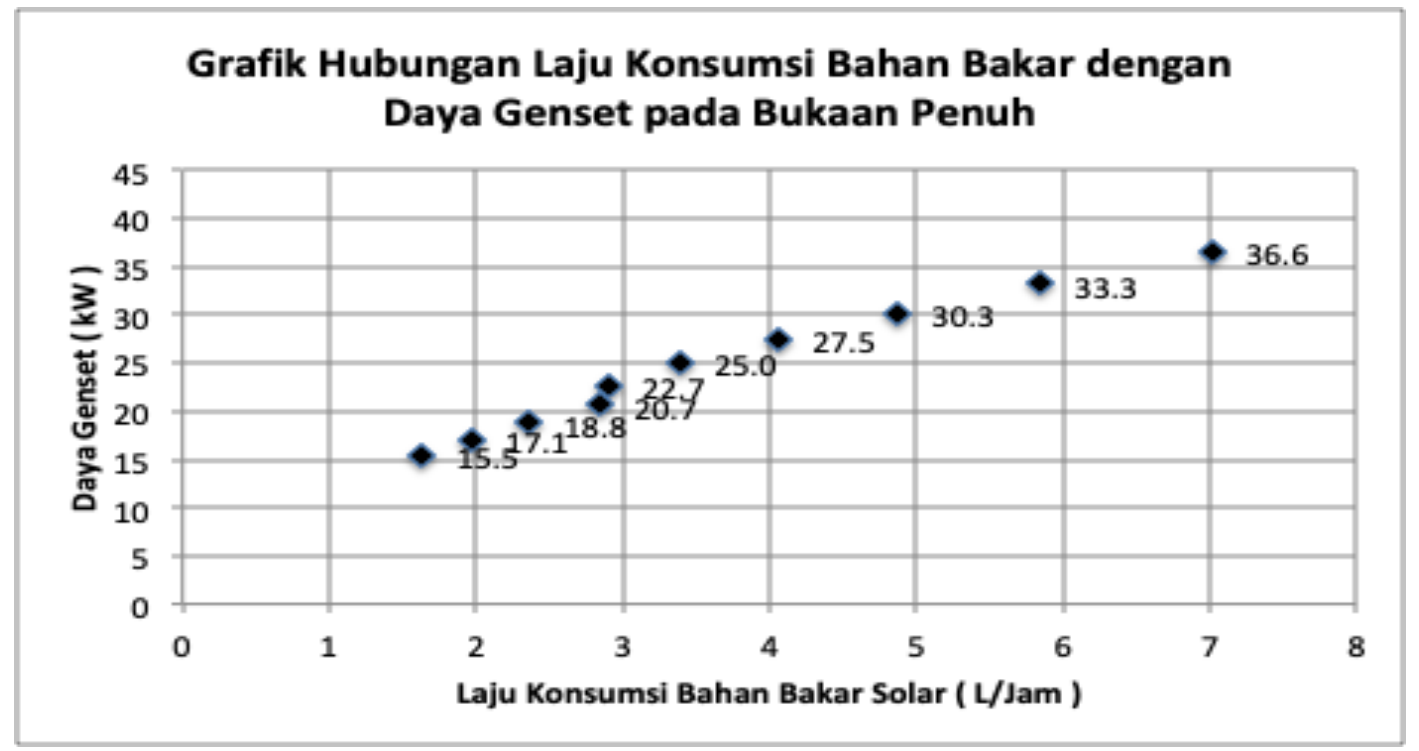

Grafik 11 Hubungan Konsumsi Bahan Bakar Solar dengan Daya Genset pada Bukaan Penuh

Pada Grafik 11 menunjukkan bahwa pada bukaan penuh, bertambahnya konsumsi bahan bakar solar mempengaruhi peningkatan daya genset. 


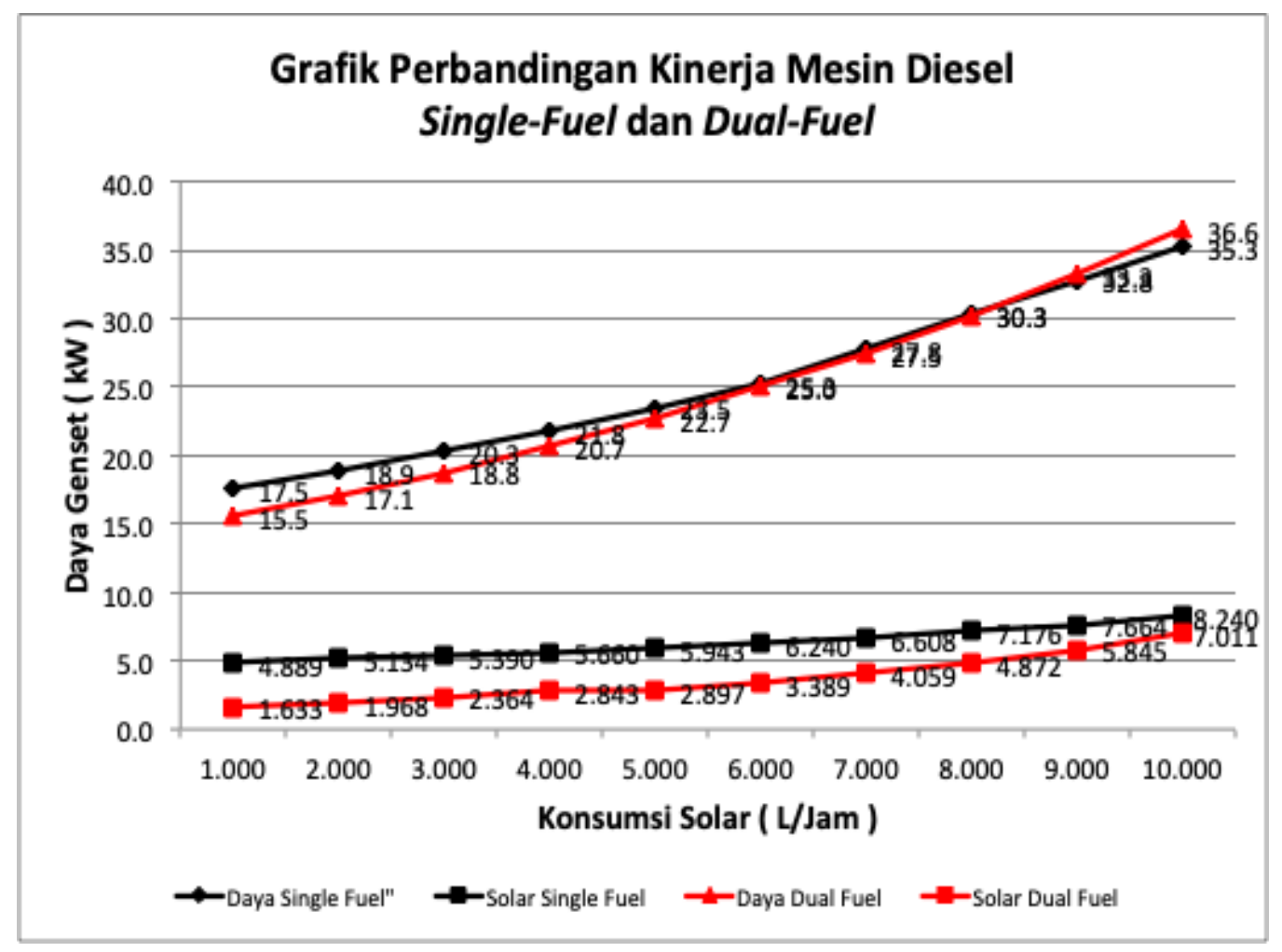

Grafik 12 Perbandingan Kinerja Mesin Diesel Single-Fuel dan Dual-Fuel

Pada Grafik 12 menunjukkan bahwa pada Kinerja Mesin Diesel Dual-Fuel menghasilkan daya genset minimum sebesar $15.5 \mathrm{~kW}$ dan maksimum sebesar $36.6 \mathrm{~kW}$ serta memerlukan konsumsi solar minimum sebanyak $1.633 \mathrm{~L} /$ jam dan 7.011 L/Jam sedangkan Single-Fuel menghasilkan daya genset minimum sebesar $17.5 \mathrm{~kW}$ dan maksimum sebesar $35.3 \mathrm{~kW}$ serta memerlukan konsumsi solar minimum sebanyak 4.889 L/Jam dan 8.240 L/Jam.

Dari Data ini dapat diperoleh persentase substitusi gas hasil gasifikasi biomassa sabut kelapa terhadap bahan bakar solar menggunakan persamaan :

\section{Substitusi bb syngas $=$}

$\frac{\text { Total Konsumsi } b b \text { solar singlefwel-Total Konsumsi } b b \text { solar dualf wel }}{\text { Total Konsumsi } b b \text { solar singlefuel }} \times 100 \%$

$$
\text { Substitusi bb syngas }=\frac{62.944-36.881}{62.944} \times 100 \%=41.4 \%
$$

\section{SIMPULAN}

Pada konfigurasi laju alir udara pembakaran 50\% (bukaan setengah) menghasilkan daya genset $12 \mathrm{~kW}$, konsumsi bahan bakar solar $1.747 \mathrm{~L} / \mathrm{Jam}$ dan konsumsi sabut kelapa $7.5 \mathrm{~kg} / \mathrm{Jam}$ lebih kecil dibandingkan dengan laju alir udara pembakaran $100 \%$ (bukaan penuh) dengan daya genset $36.6 \mathrm{~kW}$, konsumsi bahan bakar solar 7.011 L/Jam, dan konsumsi sabut kelapa 26.4 $\mathrm{kg} / \mathrm{Jam}$. Apabila ingin mencapai daya yang sama, pada bukaan setengah memerlukan waktu dan kinerja mesin 3.05 kali lebih lama untuk mencapai daya $36.6 \mathrm{~kW}$ seperti yang dihasilkan pada saat bukaan penuh. Namun dilihat dari konsumsi bahan bakar total yang digunakan pada saat bukaan setengah akan lebih irit dibandingkan dengan bukaan penuh. Hal ini dapat diartikan bahwa konfigurasi laju alir udara pembakaran (AFR) yang baik digunakan untuk mencapai daya genset maksimal dan konsumsi bahan bakar minimum adalah laju alir udara pembakaran 50\% (bukaan setengah). 
Jurnal METTEK Volume 5 No 1 (2019) pp 26 - 36

ojs.unud.ac.id/index.php/mettek

Pada saat kinerja mesin diesel dual-fuel dibandingkan dengan kinerja mesin diesel singlefuel dapat disimpulkan bahwa Kinerja Mesin Diesel Dual-Fuel menggunakan bahan bakar biomassa sabut kelapa mampu mengurangi konsumsi solar sebesar $41.4 \%$.

\section{DAFTAR PUSTAKA}

[1] Dzulfansyah D, 2013, "Simulasi Numerik Untuk Memprediksi Kinerja Reaktor Gasifikasi Sabut Kelapa Tipe Downdraft".

[2] Firman M, 2018, "Perancangan Sistem Pembangkit Listrik Tenaga Biomassa Berbahan BakarBambu Kapasitas 700kw Di Kepulauan X”.

[3] Florian W dkk , 2014, "Pemanfaatan Limbah Sabut Kelapa dan Pengaruhnya Terhadap Variasi Beban Motor Listrik Dengan Menggunakan Alat Gasifikasi Tipe Downdraft”.

[4] Hidayat A, 2014, "Karakterisasi Proses Gasifikasi Biomassa Pada Reaktor Downdraft Sistem Batch Dengan Variasi Air - Fuel Ratio (AFR) Dan Ukuran Biomassa”.

[5] Najib, L dan Darsopuspito, S. 2012. "Karakterisasi Proses Gasifikasi Biomassa Tempurung Kelapa Sistem Downdraft Kontinyu dengan Variasi Perbandingan UdaraBahan Bakar (AFR) dan Ukuran Biomassa".

[6] Priyati, A dkk. 2014. "Karakteristik Suhu dan Produksi Gas Dengan Variasi Laju Input Udara Pada Proses Gasifikasi Tandan Kosong Kelapa Sawit Menggunakan Inverted Downdraft Gasifier".

[7] Raveendran K, Ganesh A, Khilart KC, 1995, "Influence of Mineral Matter on Biomass Pyrolysis Characteristic. Fuel".

[8] Rizkal A dan Sudarmanta B, 2016, "Karakterisasi Unjuk Kerja Diesel Engine Generator Set Sistem Dual Fuel Solar-Syngas Hasil Gasifikasi Briket Municipal Solid Waste (MSW) Secara Langsung”.

[9] Subroto, 2017, “Kinerja Tungku Gasifikasi Downdraft Continue Bahan Bakar Sekam Padi”.

[10] Sulistyanto A, 2006, "Karakteristik Pembakaran Biobriket Campuran Batubara dan Sabut Kelapa".

[11] Susanto, H., 2010, "Sekilas tentang Teknologi Gasifikasi”.

[12] Suyitno, 2009, Energi dari biomassa: potensi, teknologi, strategi. 